JESTT Vol. 1 No. 9 September 2014

\title{
EFEKTIVITAS MEMBERDAYAKAN EKONOMI PADA PROGRAM KOMUNITAS USAHA MIKRO MUAMALAT BERBASIS MASJID DI MASJID MIFTAHUL JANNAH SURABAYA
}

\author{
Hanif Ardiansyah \\ Mahasiswa Program Studi S1 Ekonomi Islam - Fakultas Ekonomi dan Bisnis-Universitas \\ Airlangga \\ Email : abu.khanif@gmail.com \\ Dr. Muhamad Nafik H.R. \\ Departemen Ekonomi Syariah-Fakultas Ekonomi dan Bisnis-Unversitas Airlangga \\ Email : manhard999@yahoo.com
}

\begin{abstract}
:
The porpose of this research is to find out the effectiveness of Mosque-based Microbusiness Community Program to empowering mustahiq's economy at Miftahul Jannah Mosque Surabaya.

The research method of this research is a qualitative approach, case studies strategy, and descriptive analysis techniques which collecting data through interview, and observation. The informants are members of Mosque-based Microbusiness Community Program at Miftahul Jannah Mosque Surabaya, consist of seven people who had attanded the program and has recieved assistance zakat productive in the form venture capital from Baitul Maal Muamalat through Mosque-based Microbusiness Community Program (KUM3).

Based on the results of the research is Mosque-based Microbusiness Community Program effective to empower mustahiq's economy use productive zakat consist of venture capital, the mosque has a maximum role to facilitate the distribution of productive zakat from Baitul Maal Muamalat to mustahiq evidenced by increasing three indicators, namely ruhiyah, partisipation, and business.
\end{abstract}

Keyword : KUM3 program, mosque, effective, empowerment, business

\section{PENDAHULUAN}

Kemiskinan masih menjadi isu utama yang menjadi bahan pembicaraan ekonom-ekonom dunia untuk segera dicarikan jalan keluar. Kondisi kemiskinan di Indonesia sendiri, tercatat pada September 2013 jumlah penduduk miskin tercatat sebesar 28,55 juta orang atau 11,47 persen meningkat 280 ribu orang dibandingkan pada bulan Maret 2013 (Badan Pusat Statistika Indonesia, 2013). Kemiskinan Indonesia tercermin pada kondisi suatu daerah tertentu. Sebut saja Surabaya, Surabaya merupakan kota terbesar kedua di
Indonesia yang berada di propinsi Jawa Timur. Rencana Pembangunan Jangka Menengah Daerah (RPJM) kota Surabaya tahun 2010-2015 tercatat, tingkat kemiskinan atau proporsi jumlah orang miskin dibandingkan dengan jumlah penduduk keseluruhan tahun 2005 sekitar $13,8 \%$ yang terus meningkat hingga $18,1 \%$ pada tahun 2009 atau tercatat sebanyak 118.225 RTM (Rumah Tangga Miskin) dan tahun 2010 sebanyak 110.117 RTM. Banyaknya jumlah penduduk miskin tersebut menjadi salah satu permasalahan kota Surabaya khususnya dalam pemenuhan hak-hak dasar manusia, 
walaupun masih ada permasalahan lain yang menjadi perhatian khusus pemerintah kota Surabaya.

Kemiskinan di dalam Islam juga dianggap sebagai sesuatu yang harus diperangi. Sebab kefakiran terkadang mendorong seseorang untuk melakukan tindakan-tindakan yang tak dibenarkan dan diharamkan oleh agama. Tidak heran jika muncul ungkapan kekafiran atau kemiskinan mendekatkan kepada kekufuran. Rasulullah Shallallahu 'Alaihi Wasallam bersabda:

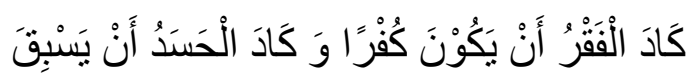

kada 'Ifaqru ayyakūnu kufraw wa kada 'lhasadu ayyasbiqa "lqadra.

"Hampir-hampir saja kefakiran akan menjadi kekufuran dan hampir saja hasad mendahului takdir" (Didhaifkan oleh Syaikh Al-Albani dan lainnya).

Walaupun hadist ini tidak bisa dijadikan hujjah atau dasar untuk dijadikan pedoman, namun ungkapan ini ada korelasi yang positif pada kenyataan yang terjadi saat ini.

Oleh sebab itu, terdapat beberapa hadits yang menggabungkan keduanya dalam isti'adzah (doa memohon perlindungan). Seperti doa Nabi SAW:

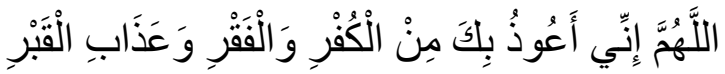

Allahumma inni a'u̇żubika mina 'Ikufri wa 'Ifaqri wa 'adābi 'lqabri.
"Ya Allah, Sesungguhnya aku berlindung kepadaMu dari kefakiran dan kekufuran serta adzab kubur" (HR. Abu Dawud, AlNasai, dan Ahmad. Dishahihkan Syaikh Al-Albani dalam dan Syu'aib al-Arnauth, beliau berkata: sanadnya kuat sesuai syarat Muslim) (Depag Rl,2007).

Al-Munawi juga menambahkan dalam Faudh al-Qadir berkata:"Digabungkannya kefakiran dengan kekufuran karena kefakiran terkadang menyeret kepada kekufuran". (diambil dari www.voaislam.com pada 13/07/2014).

Kuncoro (1997: 102-103),
mendefinisikan kemiskinan sebagai ketidakmampuan untuk memenuhi kebutuhan minimum. Kemudian diperjelas oleh konsep Sumodiningrat (1999:150), yang terkenal dengan "lingkaran setan kemiskinan" yang meliputi Keterbelakangan, Kekurangan Modal, Investasi rendah, Tabungan rendah, Pendapatan rendah, Produksi rendah, yang akhirnya menjadikan orang tersebut dikategorikan sebagai orang miskin.

Dewasa ini, lembaga-lembaga pengelola ZIS mulai banyak bermunculan dengan bermacam-macam program pemberdayaan yang mereka tawarkan. Salah satunya lembaga keuangan syariah tertua di Indonesia, yaitu Bank Muamalat yang membentuk lembaga pengelola dana ZISWAQ, dana sosial, dan dana kebajikan sendiri yang dinamakan Baitul Maal Muamalat.Baitulmaal Muamalat (BMM) merupakan yayasan yang didirikan oleh Bank Muamalat pada 16 Juni 2000 
sebagai perpanjangan tangan perseroan dalam melaksanakan kegiatan CSR dan kegiatan sosial lainnya. Selama tahun 2009 dan 2010 telah disalurkan 35\% dari alokasi dana CSR yang telah ditetapkan dalam Rapat Umum Pemegang Saham. Akses modal bagi pelaku UMKM ditengarai sebagai salah satu penyebab masalah kemiskinan yang harus disegera dicarikan solusi. Semakin dekat unit permodalan dengan mustahiq atau pelaku UMKM nonbankable, semakin mudah pula UMKM untuk mengakses modal. Semangat itulah yang mendorong BMM untuk berinisiatif bekerjasama dengan masjid untuk membantu menyalurkan dana CSR bank muamalat, dana ZIS, dana sosial dan dana lainnya kepada UMKM dengan akad Qordul Hasan. Program yang dinamakan Komunitas Usaha Mikro Muamalat Berbasis Masjid (KUM3) ini selama tahun 2010 mampu menggulirkan dana sebesar Rp 10,69 M di seluruh UMKM binaan masjid di seluruh Indonesia. Kemiskinan yang dihadapi di Indonesia merupakan masalah yang harus segera diselesaikan serta sangat dekatnya jarak dengan kelompok-kelompok mustahiq pada program Komunitas Usaha Mikro Muamalat berbasis Masjid (KUM3) ini dalam pemberdayaan dana zakat produktif, maka penulis tertarik untuk meneliti lebih jauh bagaimana efektivitas program ini dalam pemenuhan kebutuhan modal mustahiq agar tercipta masyarakat yang mandiri yang mampu merubah mustahiq menjadi muzakki? Berdasarkan rumusan masalah, maka tujuan dari penelitian ini adalah mengetahui efektivitas program KUM3 Baitul Maal Muamalat dalam pemenuhan kebutuhan modal mutahiq.

\section{LANDASAN TEORI}

\section{TEORI EFEKTIVITAS}

Efektivitas secara sederhana dapat dipahami sebagai tingkat keberhasilan suatu kebijakan atau program dalam usahanya untuk mencapai tujuan sesuai dengan perencanaan yang dinginkan sehingga menghasilkan hasil dan dampak yang sesuai dengan harapan. Efektivitas seringkali dikaitkan dengan efisiensi, namun pada penjelasanya efektivitas memiliki makna yang berbeda dengan efisiensi. Drucker (2001:15), menyatakan dimana efektivitas pada hakikatnya melakukan sesuatu yang benar (doing the riht thing) sedangkan efisiensi adalah melakukan dengan benar (doing things right). Disini terlihat bahwa Drucker menekankan konsep efektivitas lebih pada pencapaian sasaran sesuai dengan yang direncanakan.Sedangkan efisiensi lebih menekankan bagaimana sebaiknya dilakukan.

Sementara itu menurut Arens dan Loebbecke (2001:25) menyatakan bahwa "Effectiveness refers to accomplishment of objecktive, whereas efficiency refers to the resource use to achieved those objecktives". Pernyataan tersebut jelas bahwa orientasi efektivitas ada pada pencapaian tujuan dari suatu program/kebijakan.Yakni seberapa berhasilkah suatu program/kebijakan 
dapat mencapai tujuan.Sedangkan Tyson dan Jackson (2000:18) menjelaskan bahwa efektivitas dapat di definisikan sebagai kecakapan untuk menyesuaikan diri terhadap lingkungan yang berubah serta yang menjadi dasar efektivitas adalah integrasi. Jadi apabila dikaitkan dengan efektvitas kebijakan, tentunya melalui program atau kebijakan diharapkan masalah-maslah yang terjadi di masyarakat dapat berhasil direduksi menyesuaikan dengan keinginan masyarakat yang normatifnya tentu tanpa adanya suatu permasalahan di dalam lingkungan masyarakat.Atau jika di nilai dari sudut pandang masyarakat, diharapkan melalui pengambilan keputusan dengan adanya kebijakan/program maka masyarakat mampu menyesuaikan dengan kondisi lingkungan yang menjadi permasalahan yang tidak bisa di hindari oleh masyarakat. Kuncoro (2002:228) secara sederhana menjelaskan bahwa efektivitas program pembangungan dapat dilihat melalui pencapaian tujuan, manfaat, serta dampak yang dihasilkan. Proyek yang digunakan untuk mencapai suatu program pembangunan memiliki tiga unsur dalam pelaksanaannya, yaitu input, proses, dan ourput. Sebagaimana yang dijelaskan dalam Gambar 4.1. berikut ini:

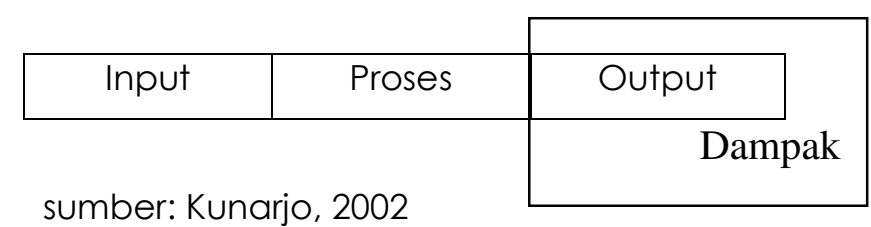

Gambar 1

Pelaksanaan Program dan Dampak
Gambar 4.1 menunjukkan proses dari awal sebuah program dibuat yang tentu saja dengan tujuan yang ingin dicapai oleh sebuah lembaga, di gambar fase ini disebut sebagai input. Kemudian program itu dijalankan atau dalam gambar 4.1 disebut proses, yang di dalamnya terlibat subjek dan objek dari program yang dijalankan. Pada akhirnya akan menghasilkan sebuah output yang merupakan representasi dari tujuan awal yang dicapai, apakah hasilnya sesusai tujuan awal atau tidak, secara otomatis akan memberikan dampak pada subjek ataupun objek program itu sendiri.

\section{TEORI ZAKAT}

Zakat memiliki beberapa arti, ditinjau dari segi bahas, yaitu al-barakatu yang berarti keberkahan, al-namma yang berarti keberesan.Sedangkan menurut etimologi (asal kata), zakat berasal dari kata "zaka" yang berarti berkah, tumbuh, bersih, suci, subur, dan baik (AshShiddieqy, 1976).Menurut istilah, zakat berarti bagian harta yang telah memenuhi syarat tertentu, yang diwajibkan oleh Allah untuk diserahkan kepada yang berhak menerimanya dengan persyaratan tertentu pula (Hafidhudin, 2002:18).

Orang yang berkewajiban mengeluarkan zakat adalah muzakki, sedangkan pihak yang berhak menerima zakat disebut mustahiq.Golongan yang berhak mendapat zakat ini dijelaskan oleh Allah SWT dalam Q.S. At-Taubah ayat 60 : 


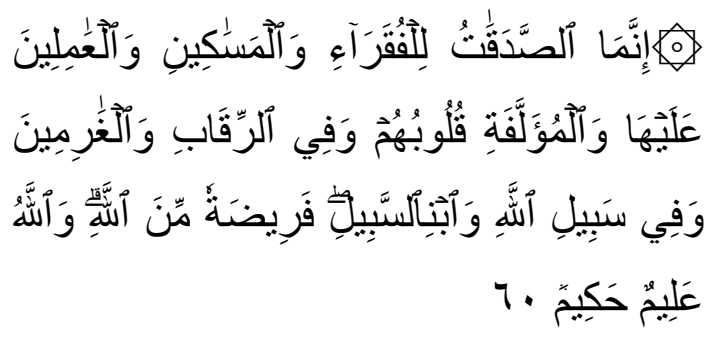

innamā 'Iśadaqatu lilfuqarā-i wa 'Imasākīni wa 'I-'āmiliina 'alayhā wa 'Imuallafati qulūbuhum wafîrriqābi wa 'Igarimina wafi sabili 'llaahi waibnissabili farīọatamminallaahi wallāhu 'alimun hakimun.

60. Sesungguhnya zakat-zakat itu, hanyalah untuk orang-orang fakir, orangorang miskin, pengurus-pengurus zakat, Para mu'allaf yang dibujuk hatinya, untuk (memerdekakan) budak, orang-orang yang berhutang, untuk jalan Allah dan untuk mereka yang sedang dalam perjalanan, sebagai suatu ketetapan yang diwajibkan Allah, dan Allah Maha mengetahui lagi Maha Bijaksana.( Q.S. At-Taubah ayat 60) (Depag RI,2007)

Setiap kewajiban yang diperintahkan Allah termasuk zakat pasti memiliki tujuan, manfaat, dan hikmah. Tujuan diperintahkannya zakat oleh Allah menurut Djuanda (2006) adalah:

a) Mengangkat derajat fakir miskin dan membantunya keluar dari kesulitan hidup serta penderitaan.

b) Membantu pemecahan permasalahan yang dihadapi oleh para mustahiq.

c) Menjembatani jurang pemisah antara si kaya dan si miskin dalam masyarakat. d) Mengembangkan rasa tanggung jawab sosial pada diri seseorang, terutama pada mereka yang punya kelebihan harta.

e) Mendidik manusia untuk berdisiplin menunaikan kewajiban dan menyerahkan hak orang lain yang ada padanya.

f) Sebagai sarana pemerataan pendapatan untuk mencapai keadilan sosial.

Sedangkan manfaat dari ibadah zakat adalah :

a) Sebagai perwujudan iman kepada Allah.

b) Karena zakat merupakan hak mustahiq, zakat berfungsi untuk menolong, membantu dan membina mereka, terutama fakir miskin kearah kehidupan yang lebih baik.

c) Zakat untuk memasyarakatan etika bisnis yang benar. Sebab zakat itu bukan membersihkan harta yang kotor, tetapi mengeluarkan bagian dari hak orang lain dari kita yang kita usahakan dengan baik dan benar.

Zakat merupakan rukun Islam ketiga setelah shalat fardu yang di dalam Al-Qur'an disebut berulang-ulang oleh Allah.Ini menunjukkan bahwa ibadah zakat mempunyai makna yang mendalam bagi segala aspek kehidupan. Dari sosial kemasyarakatan, baik zakat, infaq, maupun shadaqah memberikan hikmah yang besar dalam merealisasikan nilai harta umat Islam (Inoed ,2000:80). Jadi, zakat adalah ibadah dalm bidang 
harta yang mengandung hikmah dan manfaat yang demikian besar, mulia, baik yang berkaitan dengan dengan muzakki, mustahiq,harta yang dikeluarkannya maupun bagi masyarakat keseluruhan (Rahman, 1999:76).

Pendistribusian zakat menurut Mufraini (2006:113) pendistribusian zakat dibagi menjadi tiga yaitu distribusi konsumtif, distribusi produktif, dan investasi. Investasi yang tinggi akan meningkatkan pendapatan yang kemudian berpengaruh pada meningkatkan konsumsi dasar mustahiq, sehingga zakat akan meningkatkan agregat konsumsi dasar, yaitu akumulasi konsumsi pokok. Hal ini secara logis terjadi akibat akomodasi sistem ekonomi terhadap pelaku pasar yang tidak memiliki daya beli atau mereka yang tidak memiliki akses pada ekonomi.sehingga mereka memiliki daya beli yang memadai untuk memenuhi kebutuhan dasar.Kegiatan konsumsi merupakan variabel yang sangat positif bagi kinerja perekonomian leconomi growth).Ketika perekonomian mengalami stagnasi, seperti terjadi penurunan tingkat konsumsi, kebijakan utama yang diambil adalah bagaimana dapat menggerakkan ekonomi dengan menigkatkan daya beli masyarakat.Sehingga dapat dikatan bahwa kemampuan daya beli masyarakat menjadi sasaran utama dari setiap kebijakan ekonomi (Sakti, 2007:78).Dengan mekanisme zakat yang baik, peningkatan daya beli masyarakat tetap dapat stabil, maka zakat memiliki peran yang cukup signifikan untuk menjaga kestabilan perekonomian.

Akhirnya, implementasi sistem zakat akan dapat mengurangi kemiskinan dan pengangguran yang menjadi penyakit dalam pembangunan perekonomian suatu wilayah. Implementasi pengembangan ekonomi zakat membutuhkan keterlibatan dan kepedulian pemerintah, muzakki, dan mustahiq.Jika tidak, berarti sama saja membiarkan ketidakadilan ekonomi terjadi. Pengelolaan secara profesional dapat meningkatkan kesadarn muzakki dalam penunaian zakat.Karena masih banyak muzakki yang enggan menunaikan zakat bukan masalah belum mampu menunaikannya, melainkan kurangnya pengetahuan dan kesadaran berzakat. Penunaian zakat akan membangkitkan solidaritas sosial, mengurangi kesenjangan sosial, dan pada gilirannya akan mengurangi derajat kejahatan di tengah masyarakat. Untuk itu, pemerintah, BAZ, atau LAZ harus memiliki database mengenai muzakki dan mustahiq di wilayah kedudukannya.Hal ini menjadi sangat dibutuhkan untuk melakukan sosialisasi dan pembinaan, guna memupuk kepercayaan para muzakki, mustahiq, dan masyarakat pada umummnya terhadap pengelolaan zakat oleh Negara atau lembaga zakat (Asnaini, 2010: 30). Jadi, zakat, infaq, dan shadaqah terutama infaq dan shadaqah, dapat dimanfaatkan untuk usaha produktif apabila terdapat usaha-usaha nyata yang berpeluang menguntungkan. 
Secara garis besar, dana zakat dapat didistribusikan pada dua jenis kegiatan, yaitu kegiatan-kegiatan yang bersifat konsumtif dan produktif (Nasution et al, 2008).

\section{PEMBERDAYAAN}

Pemberdayaan berasal dari kata empowerment yang berarti penguatan.Yaitu upaya untuk mengaktualisasikan potensi yang sudah dimiliki sendiri oleh masyarakat.Jadi, pendekatan pemberdayaan masyarakat penekanannya pada pentingnya membentuk masyarakat lokal yang mandiri sebagai suatu sistem yang mengorganisir diri mereka.Pada akhirnya masyarakat sendiri yang diposisikan sebagai subjek, bukan objek (Setiana, 2007:4).

Menurut Payne yang dikutip oleh Adi (2003:115) menjelaskan bahwa pemberdayaan adalah :

"To help client gian power of decision and action over their own lives by reducingthe effect of sicial or personal block to exercising excisting power, by increasing capacity and self confidence to use power and by transferring power from the environment to clients"

"Membantu klien memperoleh daya untuk mengambil daya untuk mengambil keputusan dan menentukan tindakan yang akan ialakuakn terkait dengan diri mereka, termasuk mengurangi efek hambatan pribadi dan sosial dalam melakukan tindakan. Hal ini dilakukan melalui peningkatan kemampuan dan rasa percaya diri yang ia miliki, antara lain melalui transfer daya dari lingkungan"

Menurut Suharto

(2005:94)

pemberdayaan menunjuk pada kemampuan orang, khususnya kelompok rentan dan lemah sehingga mereka memiliki kekuatan atau kemampuan dalam (a) memenuhi kebutuhan dasarnya sehingga mereka memiliki kebebasan (freedom), dalam arti bukan saja bebas mengemukakan pendapat, melainkan bebas dari kelaparan, bebas dari kebodohan, bebas dari kesakitan; (b) menjangkau sumber-sumber produktif yang memungkinkan mereka dapat meningkatkan pendapatannya dan memperoleh barang-barang dan jasa jasa yang mereka perlukan; (c) berpartisipasi dalam proses pembangunandan keputusan-keputusan yang mempengaruhi kehidupan mereka.

Mufraini (2006 : 159) menjelaskan bahwa pola distribusi produktif yang dikembangkan pada umumnya mengambil skema qardul hasan yakni suatu bentuk pinjaman yang menetapkan tidak adanya tingkat pengembalian tertentu dari pokok pinjaman. Namun jika si peminjam tidak mampu mengembalikan pokok tersebut maka hukum zakat mengindikasikan bahwa si peminjam tersebut tidak dapat dituntut atas ketidakmampuan tersebut, karena pada dasarnya dana tersebut adalah hak mereka. Mufraini (2006: 160) menambahkan bahwa terlepas dari perdebatan pendapat dalam fiqih dan 
pola inovasi pendanaan yang diambil dari dana zakat, infaq, dan shadaqah, skema yang dikedepankan dalam pola qardul hasan sebenarnya sangat bagus.

\section{STRATEGI PEMBERDAYAAN PROGRAM KUM3}

Baitul Maal berasal dari bahasa Arab yaitu bait berarti rumah, dan al-maal yang berati harta. Jadi secara ma'na lughawi baitul maal merupakan rumah ntuk mengumpulkan atau mengelola harta, terutama dana sosial. Baitul Maal dalam perkembangannya mempunyai fungsi ganda selain mengelola dana sosial juga sebagai lembaga mikro untuk membantu permodalan masyarakat sehingga dalam penamyaanya menjadi Baitul Maal wa Tamwil. Baitul Maal Wa Tamwil (BMT) adalah balai usaha mandiri terpadu yang isinya berintikan bayt almaal wa al-tamwil dengan mengembangkan usaha-usaha produktif dan investasi dalam meningkatkan kualitas ekonomi pengusaha kecil antara lain dengan mendorong kegiatan menabung dan menunjang pembiayaan kegiatan ekonominya (Djazuli, 2002:183). Berbeda dengan Baitul Maal wa Tamwil, lembaga zakat menurut Undang-Undang No. 23 Tahun 2011 merupakan lembaga yang bertugas mengumpulkan, menyalurkan, serta pendayagunaan dana zakat.

Program Komunitas Usaha Mikro Muamalat berbasis Masjid (KUM3) merupakan program bentukan Baitul Maal Muamalat (BMM) bersaama dengan) dalam rangka pemberdayaan ekonomi umat di lingkungan masjid. Sejak mulai berdiri pada tahun 2006 hingga akhir tahun 2012, program KUM3 telah memiliki wilayah sebaran di 18 Provinsi, 114 masjid, 219pendamping, 597 kelompok dengan jumlah peserta terbanyak 7.552 mustahiq. Dana zakat yang telah digunakan untuk modal program tersebut sebesar Rp. 12.43 Milyar. (sumber: www.baitulmaal.net diakses pada 21-1-2014)

Dalam pengelolaan serta pengawasan KUM3 pihak Baitul Maal Muamalat menggunakan strategi partnership, dimana strategi ini dapat diartikan dengan menerapkan pengelolaan yang pendamping serta penanganan langsung dari pihak BMT, masjid dan sukarelawan.Dalam pelaksanaannya pengawasan serta pengelolaan ini dilakukan oleh BMT bersama masjid dan untuk pelaporan kepada BMM dilakukan melalui eMustahiq kemudian data yang telah masuk dalam e-Mustahiqnantinya juga akan dapat diketahui oleh para muzaki yang disini berperan sebagai pemberi dana.

Faktor seseorang menjadi miskin adalah kurangnya lapangan kerja dan kurangnya akses modal kerja. Kuncoro, (1997 : 102-103) mendefinisikan kemiskinan sebagai ketidakmampuan untuk memenuhi kebutuhan minimum. Kemudian diperjelas oleh konsep Sumodiningrat (1999:150), yang terkenal dengan "lingkaran setan kemiskinan" yang meliputi Keterbelakangan, 
Kekurangan Modal, Investasi rendah, Tabungan rendah, Pendapatan rendah, Produksi rendah, yang akhirnya menjadikan orang tersebut dikategorikan sebagai orang miskin.

\section{INDIKATOR KEBERHASILAN PEMBERDAYAAN}

Salah satu indikator kesuksesan suatu metode pemberdayaan terhadap masyarakat miskin adalah dengan meningkatnya kemampuan daya beli (konsumsi) masyarakat untuk memenuhi kebutuhan-kebutuhan hidup yang meliputi kebutuhan primer dan sekunder (makanan, pakaian, rumah, pendidikan, kesehatan dan rekreasi) (Rosyidi, 2006:184). Zakat akan meningkatOkan permintaan barang dan jasa karena si miskin yang dulu tidak mampu membeli maka setelah menerima zakat menjadi mampu membeli kebutuhannya, sehingga jelaslah bahwa zakat tidak menurunkan konsumsi melainkan meningkatkan konsumsi dan mendorong pertumbuhan ekonomi (Ryandono, 2008:26).

\section{PROPOSISI}

Jika program Komunitas Usaha Mikro Muamalat berbasis Masjid (KUM3) mampu memberdayakan mustahiq di sekitar lingkungan masjid binaan, maka program ini efektif untuk dijadikan model pendayagunaan dana zakat.

\section{METODE PENELITIAN}

\section{Pendekatan Penelitian}

Metode penelitian kualitatif adalah metode penelitian yang berlandaskan pada sifat postpositivisme, digunakan untuk meneliti pada kondisi obyek yang alamiah (Sugiyono, 2011:9). Metode yang digunakan dalam penelitian ini adalah studi kasus deskriptif yang bertujuan untuk menjelaskan dan menggambarkan kefektifan program KUM3 dalam memberdayakan masyarakat kurang mampu.

Menurut Yin (2011:1) secara umum studi kasus merupakan strategi yang cocok jika pokok pertanyaan suatu penelitian berkenaan dengan how atau why dimana peneliti hanya memiliki peluang yang kecil sekali atau tidak memiliki peluang untuk melakukan kontrol terhadap peristiwa tersebut.

\section{Ruang Lingkup Penelitian}

Ruang lingkup penelitian ini terbatas pada program Komunitas Usaha Mikro Muamalat Berbasis Masjid (KUM3) di masjid Miftahul Jannah Surabaya.

\section{Jenis dan Sumber Data}

Jenis data yang dibutuhkan dalam penelitian ini adalah berupa data primer karena bermaksud menggali informasi secara luas dan mendalam pada objek penellitian dengan melakukan wawancara satu persatu dengan pihak pengajar pondok pesantren. Penelitian ini menggunakan teknik purposive sampling dalam mendapatkan informan. Menurut Sugiyono (2012:218) purposive sampling adalah teknik pengambilan sampel sumber data dengan pertimbangan tertentu.

\section{Teknik Keabsahan Data}

Triangulasi data menurut Moleong (2002:330), adalah teknik pemeriksaan 
keabsahan data yang memanfaatkan yang lain. Peneliti menyimpulkan bahwa dalam meneliti dibutuhkan keabsahan agar penelitian tersebut dapat dipercaya kredibilitasnya.Penulis menggunakan triangulasi sumber karena penelitian tidak bisa diratakan seperti dalam penelitian kuantitatif, tetapi dideskripsikan, dikategorisasikan, mana pandangan yang sama, yang berbeda dan mana yang spesifik dari ketiga sumber data tersebut. Data yang telah di analisis oleh peneliti sehingga menghasilkan suatu kesimpulan, selanjutnya dimintakan kesepakatan dengan ketiga sumber data tersebut.

\section{Teknik Analisis Data}

Teknik analisis penelitian ini adalah pendekatan analisis kualitatif deskriptif. Analisis tersebut bertujuan menganalisis data studi kasus dengan membuat penjelasan (naratif) dan menggambarkan (deskripsi) kasus yang bersangkutan dan membuktikan proposisi teoritis yang telah dibuat.

\section{HASIL ANALISIS DAN PEMBAHASAN}

Faktor seseorang menjadi miskin adalah kurangnya lapangan kerja dan kurangnya akses modal kerja. Kuncoro, (1997 : 102-103) mendefinisikan kemiskinan sebagai ketidakmampuan untuk memenuhi kebutuhan minimum. Kemudian diperjelas oleh konsep Sumodiningrat (1999:150), yang terkenal dengan "lingkaran setan kemiskinan" yang meliputi Keterbelakangan, Kekurangan Modal, Investasi rendah, Tabungan rendah, Pendapatan rendah,
Produksi rendah, yang akhirnya menjadikan orang tersebut dikategorikan sebagai orang miskin. Teori lingkran setan kemiskinan Nurkse menyatakan bahwa tingkat pendapatan yang rendah akan menyebabkan permintaan rendah (pada sisi permintaan) dan tabungan yang rendah (pada sisi penawaran), sehingga tingkat investasi pun rendah. Tingkat investasi yang rendah menyebabkan kurangnya modal dan kembali menyebabkan produktivitas yang rendah (Jhingan, 2004).

Baitul Maal Muamalat membuat model program pemberdayaan dengan membuat komunitas kecil yang difokuskan di masjid, program tersebut bernama Komunitas Usaha Mlkro Muamalat berbasis Masjid (KUM3). Program ini memberikan bantuan modal usaha utamanya mustahiq di sekitar masjid binaan.

Baitul Maal Muamalat mempunyai indikator atau disebut parameter untuk mengukur keberhasilan program Komunitas Usaha Mikro Muamalat Berbasis Masjid (KUM3). Parameter ini kemudian oleh BMM dijadikan acuan untuk membuat keputusan apakah layak untuk diteruskan ke model selanjutnya atau tidak. Parameter tersebut antara lain ruhiyah, keaktifan, dan usaha peserta, parameter ini juga digunakan oleh Peneliti sebagai ukuran keberhasilan program KUM3 serta untuk melihat lebih jauh dampak yang diberikan.

Peneliti melakukan wawancara pada peserta KUM3 yang telah mengikuti program di masjid Mlftahul Jannah 
Surabaya dengan mengambil tujuh informan yang menjadi sumber informasi. Hasil temuan dilapangan menunjukkan dari keseluruhan peserta antusias mengikuti program KUM3. Terlihat dari keaktifan keseluruhan informan. Alasan mengikuti yaitu karena masjid yang digunakan untuk kegiatan KUM3 memang berada di dekat rumah keseluruhan informan sehingga mudah untuk diakses serta adanya kepercayaan dan kedekatan pada pengurus KUM3 yang berasal dari pengurus masjid itu sendiri. Alasan kedua yang menjadi motivasi informan adalah kemudahan pengurusan administrasi untuk mengikuti program KUM3 serta sistem bantuan modal bergulir yang tanpa bunga ataupun tambahan yang lain.

Parameter ruhiyah juga menunjukkan keseluruhan informan mengalami perubahan setelah mengikuti program yaitu semakin giatnya dalam melakukan sholat berjamaah, adanya peningkatan untuk membaca Al-Qur'an, serta adanya peningkatan kepekaan pada sesama anggota kelompok.Sayangnya, tidak diketahui secara mendalam kondisi ibadah setelah mengikuti program.

Namun, parameter usaha dari keseluruhan informan tidak bisa menunjukkan laporan keuangan bulanan usahanya. Keseluruhan informan yang merupakan pengusaha ini memang tidak terlalu memperhatikan berapa uang yang masuk ataupun yang keluar. Sehingga perubahan keuntungan sebelum dan sesudah mengikuti program KUM3 tidak dapat diteliti secara mendalam. Keseluruhan informan menganggap dana yang diberikan tidak terlalu signifikan untuk mengangkat usahanya. Sehingga bantuan yang diterima langsung dibelanjakan untuk penambahan kapasitas produksi atau persediaan barang usaha.

$$
\text { Hasil dari tabel } 4.8 \text { dapat }
$$
disimpulkan bahwa peranan masjid dengan membentuk komunitas kecil sangat efektif peranannya untuk mengakomodir kebutuhan modal mustahiq, hanya saja kurang maksimalnya jumlah dana bantuan yang diberikan kurang untuk ukuran perkotaan. Terlihat dari peningkatan ruhiyah dan antusiasme informan untuk mengikuti program KUM3 yang memberikan dampak secara psikologis untuk bersemangat lagi dalam menjalankan usahanya. Namun kurang maksimalnya parameter usaha karena informan menganggap dana yang diterima kurang dan tidak adanya laporan keuangan yang rapi. Sehingga tidak bisa terlihat dampaknya secara langsung. Hal ini juga diperkuat dengan informasi dari pendamping kelompok di masjid Miftahul Jannah Surabaya.

Apabila dikaitkan dengan teori Dunn (2001), yang mempunyai enam indikator kefektivan sebuah program, maka hasilnya dapat disajikan sebagai berikut :

\section{Efektivitas}

Program KUM3 di masjid Miftahul Jannah Surabaya mampu merubah 
struktur masyarakat dari sebelumnya mustahiq menjadi muzakki, walaupun belum bisa dipastikan secara quantitatif, tetapi Penulis mengacu pada konsumsi informan yang hampir keseluruhan dari hasil wawancara mengalami kenaikan tingkat konsumsi. Walapupun kenaikan konsumsi ini tidak bisa dikatakan mustahiq tersebut menjadi muzakki, karena ada masih ada kemungkinan beberapa informan belum mencapai nishab. Selain itu ada juga perubahan status dari yang sebelumnya non-bankable menjadi bankable,seperti yang dialami oleh informan ketiga. Dan yang terakhir adalah meningkatkanya pemahaman agama terutama tentang membaca Al-Qur'an

2. Efisien

Program KUM3 sangat efisien dalam mewujudkan tujuan dari program itu sendiri. Keefisienan ini dapat dilihat dari pembentukan kelompok usaha kecil, yang terdiri 20 anggota untuk 1 kelompok, setiap kelompok memiliki 1 pendamping. Sedikitnya anggota ini akan memudahkan pendamping untuk terus mengawasi setiap anggota kelompoknya, seperti yang dirasakan oleh informan 5 yang merasa diperhatikan, sehingga menimbulkan kepercayaan diri untuk terus berusaha. Selain efisien dalam hal kenggotaan kelompok, program ini juga menghemat tenaga dan waktu bagi mustahiq karena memang tidak memerlukan syarat yang menyusahkan dan jaraknya pun juga dekat dengan rumah masing-masing mustahiq.

3. Kecukupan
Program KUM3 sangat cocok untuk menyelesaikan masalah kemiskinan karena sulitnya akses modal. Sebagai mana teori kemiskinan yang menyebut bahwa tingkat investasi yang rendah menyebabkan kurangnya modal dan kembali menyebabkan produktivitas yang rendah (Jhingan, 2004). Karena KUM3 menjadikan masjid sebagai media utama aktivitasnya, sehingga setiap orang mampu mengakses modal dan akhirnya kebutuhan modal usaha mereka terpenuhi.

\section{Pemerataan}

Baitul Maal Muamalat merupakan lembaga resmi yang dimiliki oleh Bank Muamalat dan memiliki tugas menghimpun dana ZIS dan mendistribusikan secara merata melalui program-program yang dimiliki salah satunya KUM3. Selama Peneliti melakukan pengambilan data di lapangan, peserta yang dipilih memang layak mendapatkan bantuan. Misalnya saja informan keenam ibu yang harus menggantikan suami untuk menjadi tulang punggung keluarga, kemudian ada juga informan pertama yang membuka toko pracangan yang memiliki tanggungan 4 anak yang masih sekolah semua, dan lain sebagainya.

\section{Responsifitas}

Keseluruhan informan sangat antusias dalam mengikuti program KUM3 karena dari awal program ini menjadikan masjid sebagai tempat aktivitas, bantuan modal tanpa agunan dan bunga.

\section{Ketepatan}


Baitul Maal Muamalat membuat strategi yang tepat dengan bekerja sama dengan masjid sebagai pusat aktivitasnya. Sehingga, mustahiq bisa dijangkau dan tentu saja tepat sasaran karena penentuan mustahiq dibantu oleh dewan takmir masjir yang tentu saja tahu kondisi lingkungan di sekitar masjid.

\subsection{Kendala Penelitian}

Kendala yang dirasakan oleh Peneliti adalah kebersediaan informanuntuk diwawancarai karena kesibukan informan dan waktu yang dimiliki Peneliti juga terbatas. Sehingga Peneliti memutuskan untuk mengambil data dari 7 peserta dari total 20 peserta yang mengikuti program KUM3. Selain itu, peserta KUM3 tidak memiliki laporan keuangan, sehingga Peneliti kesulitan memperdalam pengambilan data tentang perubahan pendapatan setelah mengikuti program KUM3.

\section{SIMPULAN}

Program Komunitas Usaha Mikro Muamalat Berbasis Masjid (KUM3) yang telah dijalankan oleh Baitul Maal Muamalat efektif digunakan untuk model pemberdayaan mustahiq. Terlihat dari peranan yang kuat Baitul Maal Muamalat mencapai keberhasilan indikator ruhiyah, partisipasi, dan usaha mustahiq. Hampir keseluruhan mustahiq mencapai target ketiga indikator, hanya saja target usaha tidak maksimal karena bantuan modal yang diberikan jumlahnya kecil dan tidak ada laporan kevangan yang rapi sehingga tidak diketahui secara jelas perkembangan usaha setelah mengikuti program KUM3.

\section{DAFTAR PUSTAKA}

Al Qur'an Al Karim.

Antonio, M. Syafi'i. 1999. Bank Syaria: Wacana Ulama dan Cendekiawan. Jakarta:Tazkia Institute.

Arens, Alvin A.J.K Loebbecke.2001. Auditing Suatu Pendekatan Terpadu. Jakarta: Airlangga.

Asnaeni. 2010. Membangun Zakat Sebagai Upaya Membangun Masyarakat. Jurnal La_Riba. Volum IV, no. 1.

Djazuli, A. 2002. Lembaga-Lembaga Perekonomian Umat. Jakarta: PT.Raja Graindo Persada.

Hafidhudin, Didin. 1998. Panduan Praktis Tentang Zakat, Infaq, Shadaqah. Jakarta: Gema Insani. 2006. Panduan Zakat Praktis. Jakarta: Dompet Dhuafa Republika.

- 2007. Agar Harta Berkahdan Bertambah Gerakan Memberdayakan Zakat, Infaq, Shadaqah. Jakarta: Gema Insani. Jhingan, M.I. 2004.Ekonomi Pembangunan dan Perencanaan.Jakarta : PT. Raja Grafindo Persada.

Kunarjo. 2002. Perencanaan dan Pengendalian Program Pembangunan. Jakarta: UI press.

Mufraini, M. Arif. 2006. Akuntansi dan Manajemen

Zakat: 
Mengkomunikasikan Kesadaran

dan Mengembangkan Jaringan.

Jakarta: Kencana.

Qardhawi, Yusuf. 1991. Hukum Zakat.

Jakarta: Lentera.

1995. Kiat Islam

MengentaskanKemiskinan. Jakarta:

Gemalnsani Press.

. 1996. Hukum Zakat Studi

Komparasi Mengenai Status

danFilsafat Zakat Berdasar Al-

Qur'an dan Hadist. Jakarta: Mizan.

2005. Spektrum Zakat

dalamMengembangkanEkonomik

erakyatan (terj.). Jakarta: Zikrul

Hakim.

Ryandono, Muhamad Nafik Hadi. 2008.

Ekonomi Ziswaq(Zakat, Infaq,

Shadaqah, dan Waqaf). Surabaya:

IFDI dan cenforis.

Sugiyono. 2011. Metode Penelitian

Kuantitatif, Kualitatif, dan R\&D.

Bandung:Alfabeta.

Tyson,Shaun\& Tony jakson.2000. The

Essence of Organizational.

Yogyakarta: ANDI

Yin. 2002. Studi Kasus Desain \& Metode. Jakarta: PT Grafindo Persada.

Yuliana, Indah. 2012. Implementasi Pendistribusian Dana Zakat, Infaq, dan Shadaqah Perbankan Syariah Untuk Pemberdayaan Usaha Kecil Mikro di Malang. Artikel. Malang: UIN Maulana Malik Ibrahim. 